\title{
Intraluminal Pressure Variations in the Isthmus of the Porcine Oviduct after Intrauterine Insemination with Saline, Oestrogen Solution or Boar Seminal Plasma
}

\author{
By A. Pettersson, S. Einarsson and H. Kindahl
}

Department of Obstetrics and Gynaecology, Faculty of Veterinary Medicine, Swedish University of Agricultural Sciences, Uppsala, Sweden.

\begin{abstract}
Pettersson, A., S. Einarsson and H. Kindahl: Intraluminal pressure variations in the isthmus of the porcine oviduct after intrauterine insemination with saline, oestrogen solution, or boar seminal plasma. Acta vet. scand. 1993, 34, 109-116. - The purpose of this study was to investigate if an intrauterine deposition of saline, boar seminal plasma, or an oestrogen solution containing $11.5 \mu \mathrm{g}$ oestrogens affected the intraluminal pressure in the isthmus of the oviduct in unrestrained gilts. In order to monitor variations in intraluminal pressure, 2 ultra-miniature pressure sensors, located at 2 different points along the same isthmus were used. After an initial recording period, either saline, boar seminal plasma, or the oestrogen solution was deposited directly into the uterus. Intraluminal pressure recordings were conducted up to $6 \mathrm{~h}$ after insemination, and blood samples, for monitoring oestradiol-17B and 15-ketodihydroprostaglandin $F_{2 \alpha}$ levels, were collected. None of the inseminates had any consistent effect on the intraluminal pressure in the porcine oviduct. After deposition of the oestrogen solution, increases in the circulating levels of both oestradiol-17B and 15-ketodihydroprostaglandin $\mathrm{F}_{2 \alpha}$ were seen.
\end{abstract}

prostaglandin $\boldsymbol{F}_{2 \alpha}$

\section{Introduction}

Boar semen is exceptionally rich in oestrogens (Claus et al. 1985). Evidence has been presented suggesting that this oestrogen content enhances uterine contractions in oestrous gilts (Claus et al. 1989) by stimulating the production of endometrial prostaglandin (PG) $\mathrm{F}_{2 \alpha}$ (Claus et al. 1990). Both in vivo studies using anaesthetized gilts and in vitro studies have shown that exogenous administration of $\mathrm{PGF}_{2 \alpha}$ increases the muscular activity of the porcine isthmus (Rodriguez-Martinez \& Einarsson 1985). Recently, intraluminal pressure variations in the oviductal isthmus in unrestrained conscious gilts, have been mapped for different stages of the oestrous cycle (Pettersson 1991). The aim of this study was to investigate if an intrauterine deposition of saline, oestrogen solution, or seminal plasma had an effect on the intraluminal pressure variations in the oviductal isthmus in oestrous gilts.

\section{Materials and methods}

Six sexually mature, crossbred gilts were used as test animals. Each gilt was used only once. Prior to and during the study, the animals were housed in a conventional stable. At no time during the study period were the gilts 
physically restrained. The gilts were tested for signs of standing oestrus, in the presence of a fertile boar, by experienced personnel.

In 5 gilts, 2 pressure sensors were implanted in the oviductal isthmus on the first day of standing oestrus (Day 1), and in 1 animal (gilt no. 1), on the last day of prooestrus (Day 21). The pressure sensors had an outer diameter of 1 $\mathrm{mm}$ and were each located at the distal end of a dacron catheter with an electrical connector at its proximal end (PR-249, Millar Instr., USA.). The pressure sensors were placed at 2 different points along the same isthmus. The method for implanting the pressure sensors has previously been described in detail (Henriksson et al. 1987). Each gilt was also equipped with a chronic intrauterine catheter, contralateral to the pressure sensor carrying oviduct. The distal end of an approximately 70 $\mathrm{cm}$ long piece of silastic tubing $(3.2 \mathrm{~mm}$ o.d, $1.6 \mathrm{~mm}$ i.d., Silastic, Dow Corning, USA) was passed through a small incision at the tip of the uterine horn $5 \mathrm{~cm}$ into the uterus. The proximal end of the silastic tubing was passed subcutaneously to the lumbar back, where it was exposed, and a three-way cannula was fixed in its proximal end. The exposed chronic intrauterine catheter and the electrical connectors of the pressure sensors were placed in a canvas bag, sutured to the lumbar back of the animal.

Each gilt was also equipped with a chronic jugular vein catheter for blood sampling (Rodriguez \& Kunavongkrit 1983). Blood samples were collected every $30 \mathrm{~min}$ during the test period. All blood samples were collected into heparinized Vacutainer ${ }^{\circledR}$ tubes (Becton and Dickinson, USA) and immediately centrifuged. Plasma was removed and stored at $-20^{\circ} \mathrm{C}$. The blood samples collected and the seminal plasma used for insemination were analysed by radioimmunoassay for concentrations of oestradiol-17ß (Boilert et al.
1973) and oestrone sulphate (Kindahl et al. 1982). Furthermore, the plasma samples were analysed for 15-ketodihydro-PGF $2 \alpha$ (Granström \& Kindahl 1982). The methods for oestradiol-17ß and 15-ketodihydro- $\mathrm{PGF}_{2 \alpha}$ have earlier been validated for the porcine species (Kunavongkrit et al. 1983).

The study was conducted on the day following operation. After an initial period of intraluminal pressure recordings, an intrauterine deposition, consisting of either $50 \mathrm{ml}$ saline with $100 \mu \mathrm{l}$ ethanol, $50 \mathrm{ml}$ seminal plasma from a fertile boar, or $50 \mathrm{ml}$ of an oestrogen solution composed of $50 \mathrm{ml}$ saline with the addition of $11.5 \mu \mathrm{g}$ oestrogens $(5 \mu \mathrm{g}$ oestradiol $+2 \mu \mathrm{g}$ oestrone $+4.5 \mu \mathrm{g}$ oestrone sulphate) and $100 \mu \mathrm{l}$ ethanol, was made. The concentration of the oestrogens in the oestrogen solution was comparable to that which can be found in boar semen (Hoang-Vu 1987). All intrauterine depositions were made using conscious gilts, exhibiting standing oestrus, in the presence of a boar. Gilt no. 1 received saline with $100 \mu \mathrm{l}$ ethanol on day 1 of the oestrous cycle while gilt no. 2 received the same deposition on day 2 . In the remaining gilts, the uterine deposition was made on day 2 . Gilts no. 3 and 4 received oestrogen solution while gilts no. 5 and 6 received seminal plasma. Registration of intraluminal pressure fluctuations in the isthmus of the oviduct was continued for up to $6 \mathrm{~h}$ after treatment. The gilts could move, eat and drink as usual during the entire test period. All movements made by the animals were carefully noted, directly as they occurred on the recordings.

After completion of the recordings, removal of the pressure sensors was performed by laparotomy. Prior to removing the sensors, it was confirmed that the position of each sensor was correct. The oviduct was examined for adhesion and the ovaries were carefully inspected in order to determine if ovulation had oc- 


\section{$\mathrm{mmHg}$}

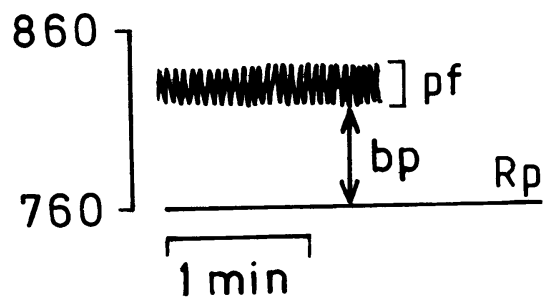

Figure 1. Example of phasic fluctuations in the isthmus. Rp: atmosphere pressure, bp: base pressure, pf: phasic pressure fluctuations.

curred. After slaughter, which occurred at a later date, sections of both oviducts from each gilt were removed for histological comparison under a light microscope.

Prior to implantation, the pressure sensors were calibrated so that the base-line was set equivalent to the atmospheric pressure of the operation day. Since the atmospheric pressure was a known value, the actual pressure in the isthmus could be established. All calculations were based on recordings obtained from the distal pressure sensor. The proximal pressure sensor was used for determining the propagation direction of outbursts of increased intraluminal pressure. Intraluminal pressure in the oviduct could be described as being composed of a base pressure upon which phasic pressure fluctuations are superimposed (Fig. 1).

The phasic pressure variations could be arranged in a way, irregular or regular pattern, with stable resting pressures and amplitudes. The base pressure was defined as being equivalent to the lowest resting pressure of the phasic pressure fluctuations over a $10 \mathrm{~min}$ period. The total pressure for the same period was defined as the sum of the mean amplitude of the phasic pressure fluctuations during 2 nonconsecutive min during which the animal was relatively still, and the base pressure.
Outbursts of increased intraluminal presssure were defined as marked increases in intraluminal pressure, where the lowest resting pressure of the phasic pressure fluctuations at the peak of the outburst was greater than the total pressure of the registration period. Total pressure, base pressure and the frequency and pattern of the phasic pressure fluctuations were determined for 10 min periods, every 10 to 20 min during the test period.

\section{Results}

The seminal plasma deposited in gilt no. 5 contained $11.6 \mathrm{ng}$ oestradiol-17ß and $1.6 \mu \mathrm{g}$ oestrone sulphate, while the seminal plasma deposited in gilt no. 6 contained 83 ng oestradiol- $17 \beta$ and $15.4 \mu \mathrm{g}$ oestrone sulphate.

As seen in Table 1, none of the intrauterine depositions increased the intraluminal pressure in the isthmus of the oviduct. Instead, the frequency of the phasic pressure fluctuations tended to decrease in some of the gilts. This decrease could not be correlated to any specific intrauterine deposition. The intrauterine depositions did not affect the pattern of the phasic pressure fluctuations. Occasional outbursts occurred prior to and after treatment. No predominance of any particular propagation direction could be seen.

After treating gilts no. 3 and 4 with the oestrogen solution, peripheral plasma levels of oestradiol-17ß started to increase and high levels were measured within 30 min after treatment. In gilt no. 3 , oestradiol-17ß levels declined within $160 \mathrm{~min}$, although the low pretreatment levels were not attained. A slight increase was seen 30 min later. In gilt no. 4 , pretreatment levels of oestradiol-17ß could be measured $90 \mathrm{~min}$ after the initial increase. Two slight increases in oestradiol-17ß were measured 60 and 180 min later (Fig. 2). Peripheral plasma levels of oestrone sulphate remained unaltered after the oestrogen treat- 


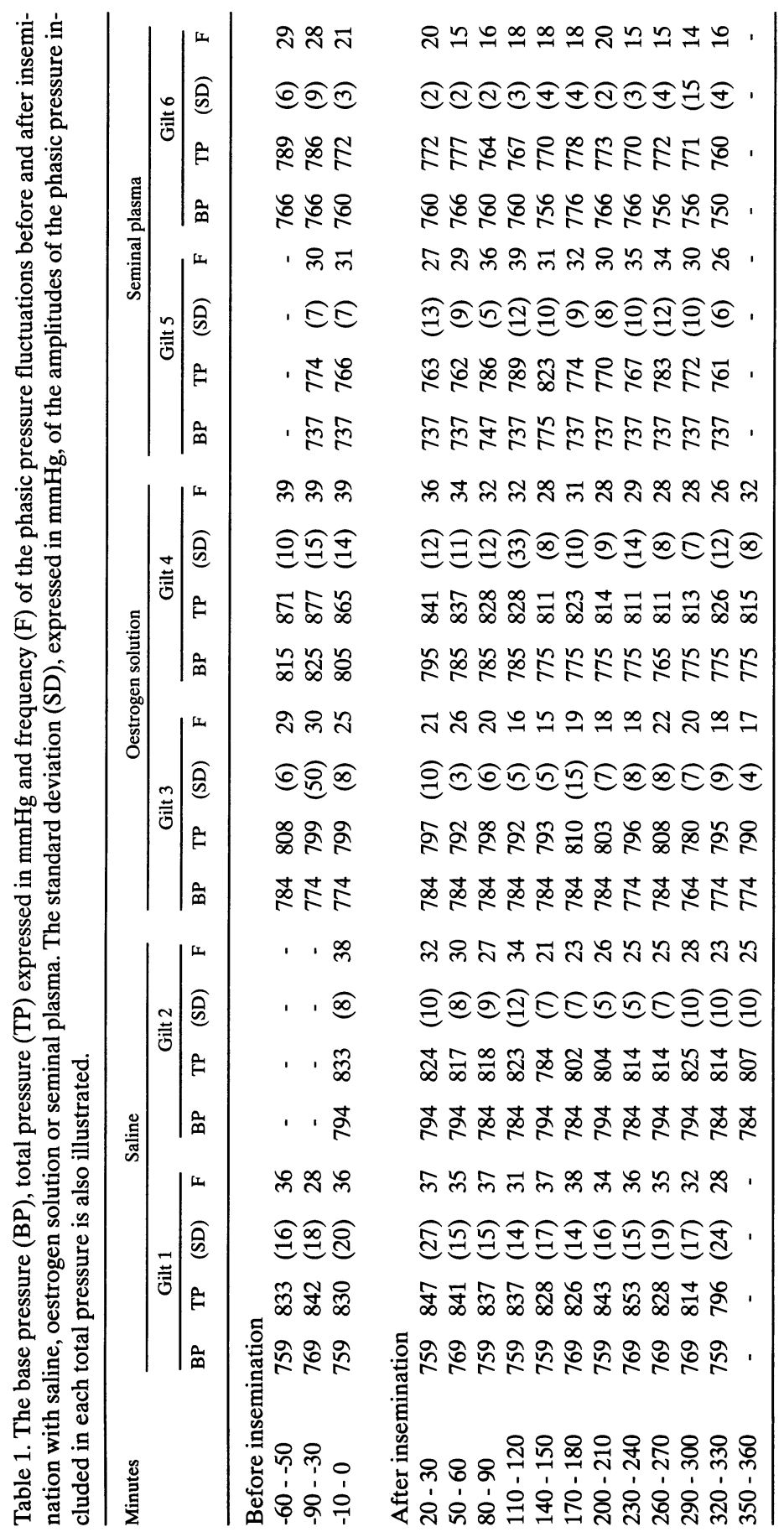



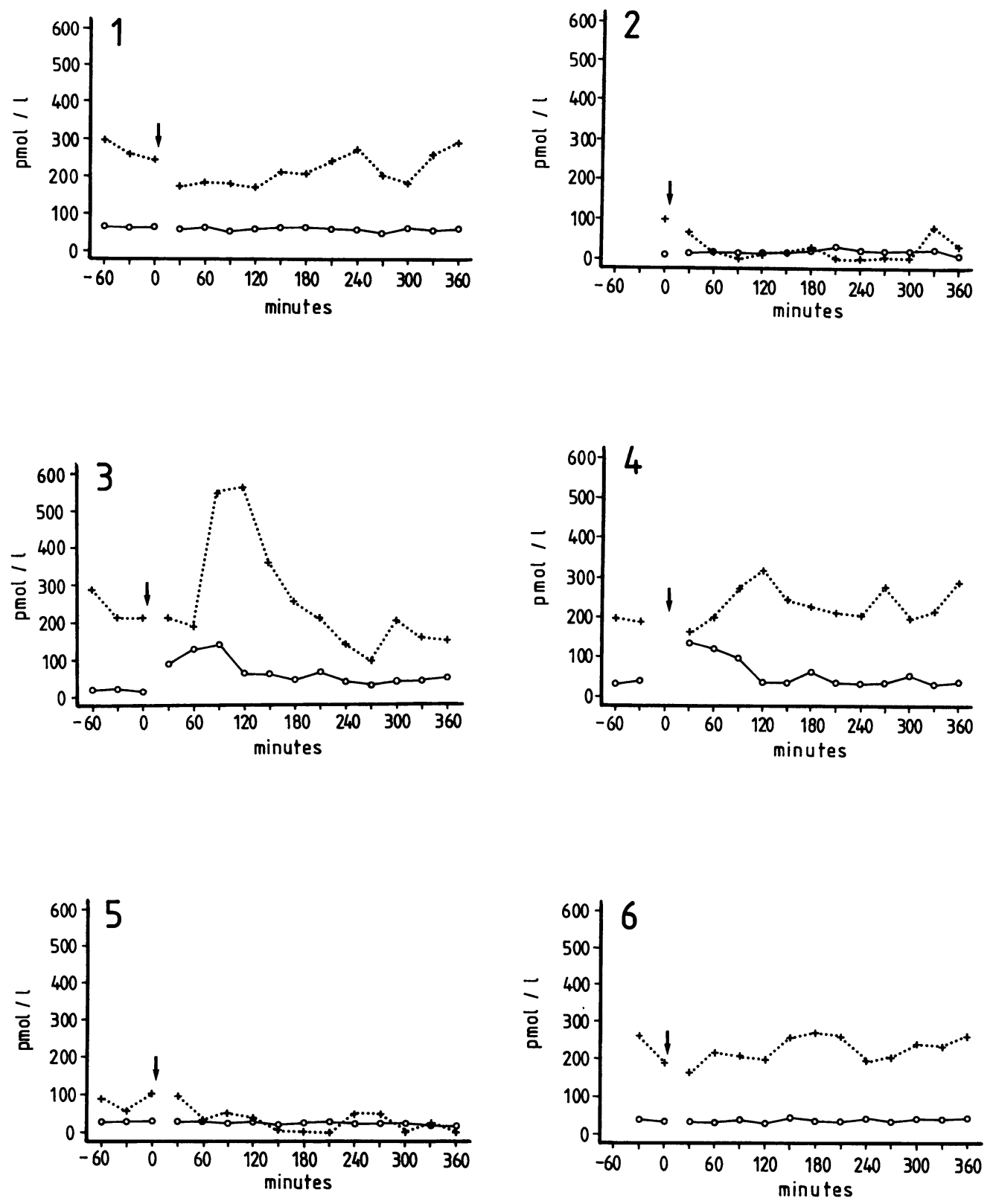

Figure 2. Peripheral plasma levels of oestradiol-17ß and 15-ketodihydro- $\mathrm{PGF}_{2 \alpha}$ before and after intrauterine deposition of saline with $100 \mu \mathrm{l}$ ethanol (1= gilt no. $1 ; 2=$ gilt no. 2$)$, oestrogen solution ( $3=$ gilt no. $3 ; 4=$ gilt no. 4) or seminal plasma $(5=$ gilt no. $5 ; 6=$ gilt no. 6$)$. The arrow indicates the time of intrauterine deposition, +--+ indicates 15 -ketodihydro-PGF ${ }_{2 \alpha}$ while $\mathrm{o}-\mathrm{-}-\mathrm{o}$ indicates oestradiol-17B. 
ment. Increased levels of 15-ketodihydro$\mathrm{PGF}_{2 \alpha}$ in peripheral circulation were measured within $60 \mathrm{~min}$ following the initial increase in oestradiol-17ß (Fig. 2) in both gilts no. 3 and 4 . The smaller increase in oestradiol$17 \beta$ in gilt no. 3 was followed by an increase in 15-ketodihydro $\mathrm{PGF}_{2 \alpha}, 90 \mathrm{~min}$ later. In gilt no. 4 , the first small increase in oestradiol-17ß was similarly followed by an increase in 15-ketodihydro-PGF $2 \alpha 90$ min later, while 15-ketodihydro-PGF ${ }_{2 \alpha}$ increased within $60 \mathrm{~min}$ of the later increase in oestradiol-17ß. In gilts no. 5 and 6 , the intrauterine deposition of seminal plasma did not lead to any increase of oestradiol-17ß or 15 -ketodihydro-PGF $2 \alpha$.

All gilts that were treated on day 2 had ovulated when the pressure sensors were removed on the following day. Gilt no. 1, however, having received the intrauterine deposition on day 1 , had not ovulated. No adhesions involving the oviduct could be seen. After slaughter, histological examination under a light microscope revealed no differences between oviducts from the same animal.

\section{Discussion}

None of the intrauterine applications had any stimulating effect on the activity of the oviductal isthmus in unrestrained gilts.

Viring et al. (1980) demonstrated a swift transuterine transport. Radiolabelled compounds, suspended in $35 \mathrm{ml}$ seminal plasma, were detected in the oviduct within 5 min of the intrauterine application. The intrauterine applications in the present study, even though applied in the uterine horn contralateral to the pressure sensor carrying oviduct, can therefore be assumed to bathe both uterotubal junctions shortly after insemination. Seminal plasma has been suggested to have a relaxing effect on the isthmus in anaesthetized gilts (Viring \& Einarsson 1980). Although the frequency of the phasic pressure fluctuations had a tendency to decline in some of the gilts after receiving the intrauterine deposition, this decrease could not be attributed to any specific treatment. Further, earlier studies in unrestrained gilts have shown that during the latter part of day 2 of the oestrous cycle, the frequency of the phasic pressure fluctuations normally tends to decrease (Pettersson 1991). Evidence has been presented suggesting that the high concentration of oestrogens in boar semen may have a stimulating effect on the contractility of the porcine uterus, and that this action is mediated by an oestrogen-dependant induction of the production of prostaglandins by the uterine wall (Claus et al. 1990). In the present study, the close correlation found between the increased levels of oestradiol-17ß and 15-ketodihydro- $\mathrm{PGF}_{2 \alpha}$ in the peripheral circulation indicate that the oestrogens in the oestrogen solution did in fact stimulate prostaglandin synthesis, as suggested by Claus et al. (1990). There was no increase in the peripheral blood levels of either oestrogens or the prostaglandin metabolite when the gilts were treated with seminal plasma. One reason for this might be that the uterus may more readily absorb oestrogens from the saline solution than from the protein-rich seminal plasma. It is interesting to note that the increase in prostaglandin metabolite levels seen after oestrogen treatment did not reflect any consistent effect on the intraluminal pressure in the isthmus of the oviduct. It has previously been shown that $\mathrm{PGF}_{2 \alpha}$ has a clear contractile effect on the porcine myosalpinx when administered both in vitro and in vivo to anaesthetized gilts (Rodriguez-Martinez \& Einarsson 1985). It is possible that the prostaglandins produced in the uterus never reach the oviduct, but instead, are metabolized and inactivated in the lung. Further, it can not be excluded that the contractile effect 
of $\mathrm{PGF}_{2 \alpha}$ may have been a pharmacological response due to unphysiological amounts of $\mathrm{PGF}_{2 \alpha}$ in tissues following exogenous administration. Rodriguez-Martinez \& Einarsson (1985) also showed, in vivo in anaesthetized gilts, that the administration of $\mathrm{PGE}_{2}$ resulted in a relaxation of the oviductal isthmus during oestrus. Although oestrogens have been found to stimulate the synthesis of, in particular, $\mathrm{PGF}_{2 \alpha}$ in the rat (Ham et al. 1975), it is possible that even $\mathrm{PGE}_{2}$ production may be stimulated in the porcine species, which would have a counteracting effect on the isthmus.

\section{Conclusions}

Intrauterine deposition of $50 \mathrm{ml}$ saline, oestrogen solution or seminal plasma from a fertile boar, had no consistent effect on the intraluminal pressure in the isthmus of the porcine oviduct even though an increase in the major prostaglandin $\mathrm{F}_{2 \alpha}$ metabolite, 15-ketodihydro-PGF ${ }_{2 \alpha}$, was seen in peripheral plasma after deposition of the oestrogen solution.

\section{Acknowledgements}

This work has been supported by the Swedish Council for Forestry and Agricultural Research. Special thanks to Birgitta Berner and Marie Sundberg for secretarial help and to the Department of Clinical Chemistry for performing the steroid analysis.

\section{References}

Boilert B, Edqvist L-E, Johansson EDB, Lindberg P, Martinsson $K$ : The influence of conjugated estrogens in radioimmunoassay using different antibodies against estradiol-17ß. Steroids 1973, 22, 891-894.

Claus $R$, Ellendorff $F$, Hoang-Vu $C$ : Spontaneous electromyographic activity throughout the cycle in the sow and its change by intrauterine oestrogen infusion during oestrus. J. Reprod. Fert. 1989, 89, 543-551.

Claus R, Meyer H-D, Giménez T, Hoang-Vu C,
Münster E: Effect of seminal oestrogens of the boar on prostaglandin $F_{2 \alpha}$ release from the uterus of the sow. Anim. Reprod. Sci. 1990, 23, 145-156.

Claus R, Schopper D, Hoang-Vu C: Contribution of individual compartments of the genital tract to oestrogen and testosterone concentrations in ejaculates of the boar. Acta endocr. (Copenh.) 1985, 109, 281-288.

Granström E, Kindahl H: Radioimmunoassay of the major plasma metabolite of $\mathrm{PGF}_{2 \alpha}, 15$-keto13,14-dihydro-PGF ${ }_{2 \alpha}$. Meth. Enzymol. 1982, 86, 302-339.

Ham E.A, Cirillo VJ, Zanetti ME, Kuehl FA: Estrogen-directed synthesis of specific prostaglandins in uterus. Proc. Nat. Acad. Sci. USA 1975, 72, 1420-1424.

Henriksson A, Gustavsson A, Einarsson S: A new method for continuous recording of oviductal pressure variations in unrestrained gilts. Acta physiol. scand. 1987, 131, 303-307.

Hoang-Vu C: Elektrische Aktivität des Myometriums beim Schwein während des Zyclus und ihre Beeinflussung durch Infusion von Östrogenen in das Uteruslumen am Tag der Rausche. (Uterine electromyographic activity of the sow during the sexual cycle and after intrauterine application of seminal oestrogens at standing oestrus). Thesis Sci. Agr., Universitet Hohenheim 1987.

Kindahl H, Knudsen O, Madej A, Edqvist L-E: Progesterone, prostaglandin $\mathrm{F}_{2 \alpha}$, PMSG and oestrone sulphate during early pregnancy in the mare. J. Reprod. Fert. Suppl. 1982, 32, 353-359.

Kunavongkrit A, Kindahl H, Madej A: Clinical and endocrinological studies in primiparous zeroweaned sows: 2 . Hormonal patterns of normal cycling sows after zero-weaning. Zbl Vet.-Med. A 1983, 30, 616-624.

Pettersson A: Cyclic variations in intraluminal pressure in the isthmus of the oviduct in unrestrained gilts. J. Vet. Med. A 1991, 38, 337-343.

Rodriguez-Martinez $H$, Einarsson $S$ : Influence of prostaglandins on the spontaneous motility of pig oviducts. Anim. Reprod. Sci. 1985, 8, 259279.

Rodriguez-Martinez H, Kunavongkrit A: Chronical venous catheterization for frequent blood sampling in unrestrained pigs. Acta vet. scand. 1983, 24, 318-320.

Viring $S$, Einarsson S: Effect of boar seminal plasma on uterine and oviductal motility in oestrous gilts. Acta vet. scand. 1980, 21, 607-616. 
Viring S, Einarsson S, Jones B, Larsson K: Transuterine transport of small- and medium-sized molecules deposited in the uterus in gilts. J. Reprod. Fert. 1980, 59, 459-462.

\section{Sammanfattning}

Intraluminella tryckvariationer $i$ istmusdelen av äggledaren hos gris efter intrauterin insemination med koksaltlösning, östrogenlösning eller spermaplasma.

Sex gyltor inseminerades intrauterint med antingen $50 \mathrm{ml}$ koksaltlösning, $50 \mathrm{ml}$ koksaltslösning tillsatt med $100 \mu \mathrm{l}$ etanol, $5 \mu \mathrm{g}$ östradiol-17B, $2 \mu \mathrm{g}$ östron och $4,5 \mu \mathrm{g}$ östronsulfat eller $50 \mathrm{ml}$ seminalplasma från en fertil galt. Före inseminationen påbörjades registrer- ing av det intraluminella trycket via 2 små tryckmätare med en ytterdiameter av $1 \mathrm{~mm}$ placerade på olika ställen längs med samma isthmus. Efter ca en timme inseminerades djuren framför en galt efter utlöst ståreflex. Registrering av tryckförändringar pågick upp till 6 timmar efter insemination. Blodprov togs var 30:e minut under hela experimentet och dessa analyserades på sitt innehåll av östradiol$17 ß$ samt prostaglandinmetaboliten 15 -ketodihydroprostaglandin $\mathrm{F}_{2 \alpha}$.

Ingen av inseminationslösningarna påverkade det intraluminella trycket $\mathrm{i}$ äggledarens isthmus. Östrogen-lösningen gav en ökning av nivåerna av östradiol-17ß samt 15-ketodihydro-PGF $2 \alpha$ i den perifera cirkulationen.

(Received November 12, 1992; accepted December 1, 1992).

Reprints may be requested from: Ann Pettersson, Department of Obstetrics and Gynaecology, Faculty of Veterinary Medicine, Swedish University of Agricultural Sciences, P.O. Box 7039, S-750 07 Uppsala, Sweden. 